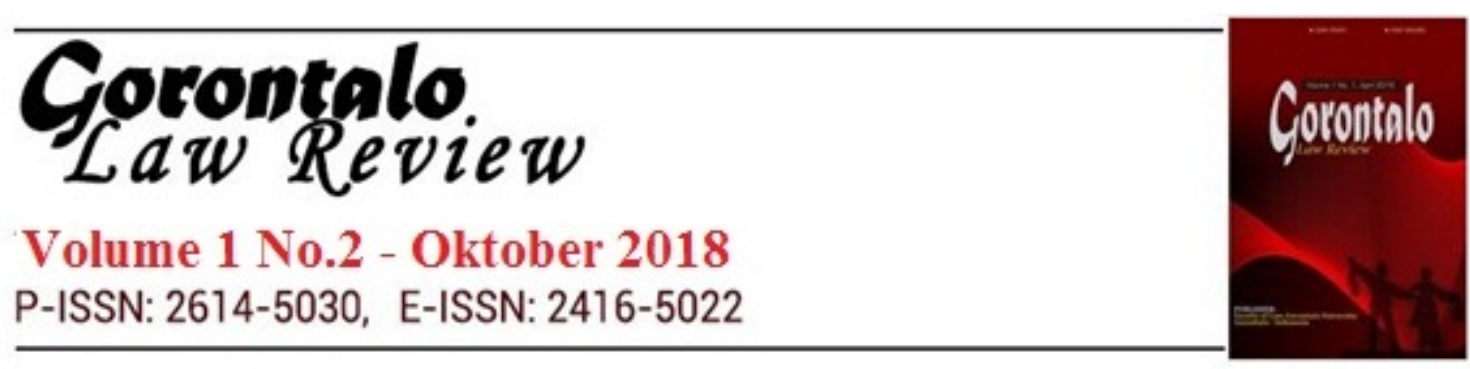

\title{
PELAKSANAAN PERLINDUNGAN HUKUM MEREK UNTUK PENGUSAHA KERAJINAN SULAMAN KARAWO DI GORONTALO
}

\author{
Yayan Hanapi \\ Fakultas Hukum Universitas Gorontalo \\ yayanhanapi@gmail.com
}

\begin{abstract}
Abstrak
the use of Trademarks and the importance of legal protection Trademarks for karawo entrepreneurs vary and also depend on their type or field of business, whether: workshop owners or batik production houses, shop owners or karawo showrooms, or owners of both. However, the average respondent stated that the main factor to attract consumers is the quality and motif or karaoke design. The average respondent also does not want to imitate the trademark of another employer, and understands that registration of the trademark rights can strengthen the protection of the use of his trademark. There does not appear to be a problem in relation to the use of Trademarks for batik products. Because there is almost no Brand dispute case among kerajanian businessmen karawo. Then, the wishes of the karawo entrepreneurs to use and register a Collective Brand are varied, but on average respondents consider that the karawo products they produce have regional characteristics.
\end{abstract}

Keywords : Legal Protection;Brands;Karawo

\begin{abstract}
Abstrak
pemanfaatan Merek dan pentingnya perlindungan hukum Merek bagi pengusaha karawo bervariasi dan bergantung pula kepada jenis atau bidang usaha mereka, apakah: pemilik workshop atau rumah produksi batik, pemilik toko atau showroom karawo, atau pemilik keduanya. Namun rata-rata responden menyatakan bahwa faktor utama untuk menarik konsumen adalah kualitas dan motif atau desain karawonya. Rata-rata responden juga tidak mau meniru Merek pengusaha lain, dan memahami bahwa pendaftaran atas hak Merek dapat memperkuat perlindungan atas penggunaan Merek miliknya. Tidak tampak adanya permasalahan dalam kaitannya dengan penggunaan Merek untuk produk batik. Oleh karena hampir tidak adanya kasus sengketa Merek di kalangan pengusaha kerajinan karawo. Lalu, keinginan para pengusaha karawo untuk menggunakan dan mendaftar Merek Kolektif pun beragam, akan tetapi rata-rata responden menganggap bahwa produk karawo yang mereka hasilkan memiliki ciri khas.
\end{abstract}

Kata Kunci : Perlindungan Hukum;Merek;Karawo 


\section{Pendahuluan}

Hak Atas Kekayaan Intelektual merupakan hak yang sudah lama diketahui oleh masyarakat didunia internasional, masalah perlindungannya pun sudah diatur oleh hukum Internasional. Memang sudah seharusnya masyarakat paham akan fungsi dari perlindungan hak kekayaan intelektual ini, karena dengan perlindungan terhadap hak ini maka akan tercipta keadilan dalam dunia bisnis suatu negara.

Hukum Hak Kekayaan Intelektual termasuk dalam kajian hukumperdata, karena ada segi dari hukum itu yang merupakan aspek hukumprivat. Yang dilindungi dalam sistem perlindungan HAKI adalah hakkekayaan intelektual dari pemilik hak. Dalam hukum perdata, disebutkan dalam Kitab Undang-Undang Hukum Perdata (KUHPerdata) Pasal 499 bahwa: "Menurut paham undang-undang yang dinamakan kebendaanialah, tiap-tiap barang dan tiap-tiap hak, yang dapat dikuasai oleh hak milik".(KUHAPer)

Hal lain yang juga menjadikan hukum HAKI termasuk dalamaspek hukum privat adalah dari segi pemberian lisensi. Agar tidakmelanggar hak atau kuasa dari si pemilik hak kekayaan intelektual,pelaksanaan pemberian lisensi harus didahului dengan adanya perjanjianlisensi antara pemohon lisensi dan pemberi lisensi yakni si pemilik hak.Makna dari lisensi itu sendiri adalah suatu bentuk pemberian izin oleh pemilik lisensi kepada penerima lisensi kepada penerima lisensi untukmemanfaatkan atau menggunakan (bukan mengalihkan hak) suatukekayaan intelektual yang dipunyai pemilik lisensi berdasarkan syaratsyarat tertentu dan dalam jangka waktu tertentu yang umumnya disertai dengan imbalan berupa royalti.

HAKI adalah hak monopoli yang mengijinkan pencipta untuk mencegah atau membatasi orang lain menggunakan ciptaan, memberikan kepada para pencipta hak eksklusif atas ciptaan dan invensi yang penting bagi masyarakat.

Dari rumusan tersebut dapat diketahui bahwa dalam pandangan Kitab Undang-Undang Hukum Perdata (KUHPerdata), yang dimaksud dengan kebendaan adalah segala sesuatu yang dapat dikuasai dengan hak milik, tanpa memperdulikan jenis atau wujudnya. Perlu diperhatikan disini bahwa penguasaan dalam bentuk hak milik ini adalah penguasaan yang memiliki nilai ekonomis. Suatu kebendaan yang dapat dimiliki tetapi tidak memiliki nilai ekonomis bukanlah kebendaan yang menjadi objek pembicaraan (Kartini Mulyadi dan Gunawan Widjaya 2003:31-32) Dari sini dapat disimpulkan bahwa hukum HAKI termasuk dalam lingkup hukum kebendaan sesuai yang diatur dalam Kitab UndangUndang Hukum Perdata (KUHPerdata).

Salah satu yang termasuk dalam lingkup perlindungan hukumHAKI adalah merek. Perlindungan hukum terhadap merek ini sudah diaturoleh hukum Indonesia dengan mengalami beberapa kali perubahan, karenadisesuaikan dengan tingkat perkembangan jaman.

Merek sangat penting dalam dunia periklanan dan pemasaran,karena publik sering mengaitkan suatu imej, kualitas atau reputasi barangdan jasa dengan merek tertentu. Sebuah merek dapat menjadi kekayaanyang sangat 
berharga secara komersial. Merek suatu perusahaan seringkalilebih bernilai dibandingkan dengan aset riil perusahaan tersebut.

Daerah Gorontalo dikenal akan budaya dan kerajinannya, salah satunya adalah kerajian sulaman Karawo. Sulaman Kerawang ini umumnya diterapkan untuk menghias bagian tertentu pada busana sebagai penambah keserasian bagi pemakainya, sehingga kelihatan lebih indah dan menarik. Ragam transparan ini menurut sejarah sudah dikenal di daerah Gorontalo sejak Tahun 1713, yang semula hanya menggunakan peralatan sederhana. Saat ini ragam dan coraknya sudah sangat bervariasi baik dalam penerapan motif desain maupun jenis bahan yang digunakan untuk menyulam.

Bicara kain kerajinan, Jawa punya kerrawang, Palembang miliki songket, Gorontalo pun tak mau kalah. Provinsi ini punya sulaman kain Kerawang. Ternyata, kerawang yang dimaksud itu berasal dari kata "Karawo" yang artinya sulaman dengan tangan. Kerajinan ini berkembang sejak lama dan kini sudah menjadi sentra kerajinan khasGorontalo. Bahkan sulaman kain kerawang kerap dijadikan baju seragam para jemaah haji dari Gorontalo. Dan tentunya warga Gorontalo harus bangga, karena nama Gorontalo harum hingga "New York Fashion Week" lewat kerajinan sulam kerawang atau sering disebut Karawo melalui gallery of Indonesia mewarnai Couture Fashion Week Di Amerika Serikat (www.bernas.id. 2017)

Tradisisi Mokarawo sebagai local wisdown ditransmisikan secara turun temurun melalui proses transfer of knowledge secara alami (outodidak). Sangat disayangkan, apabila tradisi yang ada sejak lama tidak dieksplorasi, dinovasi, dimodifikasi, dan dielaborasi demi mempertahankan eksistensinya untuk dapat di manfaatkan menjadi sumber kesejahteraan masyarakat (Rahmatiah 2017) Sulam Karawo diyakini sudah ada sejak abad 17, awalnya dilakukan oleh perempuan di daerah Ayula, yang saat itu berada di bawah pengaruh kerajaan Bulango, sekarang berada di provinsi Gorontalo. Para perempuan menjelang masa dewasanya diberikan kesibukannya untuk membuat sulam karawo, tradisi ini kemudian berlanjut untuk mereka yang dipingit menjelang pernikahannya.Dalam perkembangannya, sulaman ini kemudian dimanfaatkan untuk menghiasi baju koko yang lazim dikenakan kaum pria ke masjid atau acara keagamaan dan kematian. Karawo dengan motif sederhana juga menghiasi taplak dan sapu tangan (lenso).

Kain sulam karawo memang bukan kain sulam biasa. Tingkat kesulitan membuat sulaman karawo ini tinggi dan memerlukan ketelitian serta ketekunan luar biasa untuk membuatnya. Untuk sehelai sulaman karawo berukuran $20 \mathrm{~cm}$ × $20 \mathrm{~cm}$ saja, misalnya, perlu waktu sebulan untuk menyelesaikannya. Untuk membuat satu pola sulaman karawo memerlukan tiga orang dengan tugas berbeda (Moh. Hidayat Koniyo, 2015:).

Bertahun-tahun karawo hidup tanpa perkembangan yang berarti, motif yang sederhana, jenis kain yang terbatas, dan penggunaan yang ala kadarnya. Sulam ini karawo tetap bertahan karena masih memiliki fungsi sosial yang dibutuhkan masyarakat. Fungsi-fungsi kemasyarakatan inilah yang kemudian diadopsi dan menyebar ke daerah lain sekitar Ayula (gorontaloholiday.wordpress.com. 2018).

Menurut Yus Iryanto Abas, Ketua Jurusan Teknik Kriya Fakultas Teknik Universitas Negeri Gorontalo, memasuki era tahun 1980-an sulam Karawo ini sudah lazim dipakai masyarakat untuk baju-baju yang dipakai ke masjid 
(koko) warna putih, juga saat menghadiri upacara kematian (takziyah). Penggunaan baju sulam karawo ini juga dilakukan kaum perempuan pada acara yang sama.Dirasakan memiliki nilai ekonomi yang tinggi, pada masa selanjutnya sulam karawo diperdagangkan dalam pasar yang terbatas, masyarakat sekitar pengrajin. Lambat laun pedagang desa ini menawarkan ke pasar yang lebih luas dengan motif meningkatkan omzet penjualan.

Sebagai sebuah industri Karawo yang sudah lama berdiri maka sudah barang tentu Karawo khas Gorontalo memiliki hak atas merek dari produkproduknya dan juga produk dari para pengrajin Karawo lain yang dibeli oleh pengrajin lainnya. Berdasarkan uraian di atas, maka penulis tertarik untuk mengkaji lebih jauh mengenai hubungan hukum antara Karawo Brotoseno dengan para pengrajin karawo.

Berdasarkan hal tersebut maka perumusan masalah yang di bahas yakni bagaimana efektifitas pemanfaatan hukum merek oleh pengusaha kerajinan karawo di Gorontalo serta bagaimana strategi dari pelaksanaan dalam upaya meningkatkan pemanfaatan hukum merek oleh pengusaha.

Kegiatan penelitian pada dasarnya adalah suatu kegiatan yang terencana dandilakukan dengan metode ilmiah serta bertujuan untuk mendapatkan databaru. Pengertian dari penelitian itu sendiri adalah suatu kegiatan ilmiah yang dilakukan oleh manusia untuk menyalurkan hasrat ingin tahu yang telah mencapai taraf ilmiah yang disertai dengan suatu keyakinan bahwa setiap gejala akan dapat ditelaah dan dicari hubungan sebab akibatnya atau kecenderungan yang timbul (Soerjono Soekanto, 1986 ).

Penelitian menggunakan metode non doktrinal karena dalampenelitian ini hukum tidak hanya dikonsepkan sebagai keseluruhan asasasas dan kaidah yang mengatur kehidupan dalam masyarakat, melainkanmeliputi pula lembaga-lembaga dan proses-proses yang mewujudkanberlakunya kaidah-kaidah itu dalam masyarakat (Soerjono Soekanto, 1986).

\section{Pembahasan}

Tradisi mokarawo atau membuat sulaman adalah sepenggal sejarah yang pernah diselamatkan kaum perempuan Gorontalo. Dulu Belanda berupaya menghilangkan berbagai tradisi dan identitas lokal. Tradisi ini sudah ada sejak tahun 1600-an, jauh sebelum Belanda berkuasa di wilayah ini tahun 1889.

Saat Belanda masuk ke wilayah ini ada dua peristiwa penting yang mewarnai sejarah Gorontalo. Pertama, banyaknya warga masuk dan menetap di hutan dan wilayah terpencil karena enggan membayar pajak kepada Pemerintah Belanda. Keturunan orang-orang ini hingga kini masih berdiam di hutan dan wilayah terpencil, yang oleh warga Gorontalo dikenal dengan sebutan Polahi.Upaya penghapusan segala bentuk tradisi, adat, dan hal-hal terkait berkesenian atau kebudayaan yang ada pada masyarakat Gorontalo. Saat itu Belanda melihat kekuatan orang Gorontalo terletak pada adat, budaya, dan tradisi. Karena itu, dilaranglah berbagai aktivitas yang terkait dengan adat dan tradisi.

Hengkangnya Belanda tidak serta-merta membuat karawo keluar dari "persembunyian". Situasi saat itu dan trauma membuat tradisi mokarawo tetap dilakukan di dalam ruang tersembunyi. Karawo mulai kembali muncul sekitar akhir tahun 1960-an, tapi belum merupakan produk yang dijual secara bebas seperti barang lain. Saat itu jika ada yang berminat pada 
karawo, mereka akan datang langsung ke penyulam dan memesan. Karawo kerap dibayar menggunakan uang, kerap pula dibarter dengan barang kebutuhan lain.Pernah diselamatkan dari ancaman kepunahan saat agresi Belanda dan mengalami masa jaya, kini karawo kembali berada di bawah bayang-bayang kepunahan. Penyebabnya adalah kurangnya generasi muda yang berminat memakai karawo sebagai pakaian, apalagi sebagai penyulam. Saat ini karawo umumnya dilakukan ibu rumah tangga yang menyebar di sejumlah wilayah di Gorontalo.

\section{a. Aspek Pemanfaatan Hukum Merek}

Black"s Law Dictionary mendefiniskan Merek sebagai "A word, phrase, logo or other graphic symbol used by a manufacturer or seller to distinguish its product from those of others". Sementara, menurut World Intellectual Property Organization (WIPO) Intellectual Property Handbook, Merek diartikan sebagai "... any sign that individualizes the goods of a given enterprise and distinguishes them from the goods of its competitors". Dalam definisi WIPO tersebut dikemukakan bahwa Merek harus memiliki daya pembeda (it must be distinctive) dan tidak boleh memiliki potensi untuk mengelabui (it should not be deceptive). Sementara, dalam the Agreement on Trade Related Aspects of Intellectual Property Rights (TRIPs), Merek diatur dalam Article 15.1 yang menyebutkan bahwa "Merek dagang adalah setiap tanda atau kombinasi dari tanda yang mampu membedakan barang atau jasa dari satu badan ke badan usaha lain. Tanda tersebut meliputi kata, termasuk nama perorangan, surat, angka, unsur-unsur figuratif dan kombinasi warna, juga kombinasi tanda" (UU Merek,Pasal 15 TRIPs).

Menurut Undang-Undang Nomor 15 Tahun 2001 tentang Merek ("UU Merek"), Merek adalah tanda yang berupa gambar, nama, kata, huruf-huruf, angka-angka, susunan warna, atau kombinasi dari unsur-unsur tersebut yang memiliki daya pembedadan digunakan dalam kegiatan perdagangan atau jasa. Dalam hal ini, Merek dapat dibedakan menjadi dua jenis, yakni Merek Dagang yang digunakan pada barang yang diperdagangkan, dan Merek Jasa yang digunakan pada jasa yang diperdagangkan.

Dari sudut pandang konsumen, Merek dapat menjadi penanda dari suatu produk yang menunjukkan asal produsennya, sehingga ia dapat memilih produk tertentu dari produsen tertentu tersebut, diantara produkproduk lainnya yang sejenis. Pemilihan produk berdasarkan Merek tersebut dapat dilakukan oleh karena keberhasilan pemasaran produk, reputasi yang dimiliki oleh si produsen (good will), (Arthur R. Miller dan Michael H. Davis :1990) jaminan kualitas atas produk, atau bahkan atas dasar pertimbangan bahwa produk tersebut memenuhi selera konsumen. Sehingga, terkadang dapat melekat image tertentu di mata konsumen terhadap suatu Merek atas produk tertentu (Ihsan Budi Maulana, Ridwan Khairandy dan Nurjihad, 2000). Image tersebut berkaitan dengan reputasi dari produk atau produsennya, dan konsumen dapat menjadi loyal untuk terus membeli atau menggunakan produk dengan Merek tersebut karena reputasi atau image yang terbangun.

Sementara, berkaitan dengan Merek Kolektif, UU Merek menyebutkan bahwa Merek Kolektif merupakan Merek yang digunakan pada barang dan/atau jasa dengan karakteristik yang sama yang diperdagangkan oleh beberapa orang atau badan hukum secara bersanasama untuk membedakan 
dengan barang dan/atau jasa sejenis lainnya. Klasifikasi Merek Kolektif tidak membuat adanya tiga jenis merek. Jenis Merek tetap hanya dua yaitu Merek Dagang dan Merek Jasa. Perbedaan pada Merek Kolektif terletak pada subyek pemakai merek, yaitu boleh secara kolektif, sementara Merek Dagang atau Jasa biasanya digunakan oleh perorangan. Merek Kolektif boleh digunakan oleh beberapa orang (gabungan orang) atau boleh juga badan hukum (gabungan korporasi).

Menurut WIPO IP Handbook, Merek Kolektif biasanya dimiliki oleh sebuah asosiasi atau perusahaan, yang anggotanya dapat menggunakan Merek Kolektif tersebut untuk memasarkan produk-produk yang mereka miliki. Biasanya asosiasi tersebut menetapkan serangkaian kriteria bagi pengusaha yang ingin menggunakan Merek Kolektif tersebut (misalnya standar kualitas), yang memungkinkan bagi pengusaha secara individu untuk memenuhinya. Merek Kolektif merupakan cara yang efektif untuk memasarkan secara bersama produk-produk yang dihasilkan oleh suatu kelompok pengusaha yang mungkin merasa kesulitan untuk mendapatkanpengakuan konsumen dan/atau kepercayaan para penyalur utama atas produknya apabila menggunakan merek sendiri. (www.wipo.int.2018.)

Dengan mendaftarkan Merek ke Direktorat Jenderal Hak Kekayaan Intelektual ("DJHKI"), pengusaha dapat memperoleh hak Merek. Hak Merek merupakan hak eksklusif dengan jangka waktu tertentu bagi pemegang hak Merek untuk dapat menggunakan sendiri Merek tersebut atau memberi izin kepada pihak lain untuk menggunakannya. UU Merek menganut sistem konstitutif, dimana perlindungan hak Merek diberikan kepada pihak yang pertama kali mendaftarkan. Dalam hal ini, hak eksklusif atas penggunaan Merek diberikan karena adanya pendaftaran (required by registration). UU Merek mengatur bahwa pendaftaran tersebut pun harus berdasarkan suatu itikad baik. Pengaturan ini dimaksudkan untuk melindungi pemilik Merek yang tidak terdaftar, apabila ada pihak lain yang mendaftar Merek yang mirip atau sama dengan Merek si pemilik pertama tersebut. Berdasarkan ketentuan UU Merek, pendaftaran dapat memberikan hak ekslusif kepada pemilik merek guna mencegah pihak-pihak lain untuk memasarkan produkproduk yang identik atau mirip dengan produk dari pengusaha yang bersangkutan dengan menggunakan Merek yang sama dengan pengusaha, atau yang dapat membingungkan konsumen karena suatu kemiripan atau kesamaan pada Merek tersebut.

Permohonan pendaftaran Merek Kolektif pada umumnya sama dengan pendaftaran Merek biasa. Hanya saja dalam permohonan pendaftaran Merek Kolektif, harus ada pernyataan yang berisi penegasan bahwa Merek tersebut akan digunakan sebagai Merek Kolektif. Disamping itu, permohonan pendaftaran juga wajib menyertakan salinan peraturan penggunaan Merek sebagai Merek Kolektif yang ditandatangani oleh semua pemilik merek yang bersangkutan (UU ttg Merek pasal 50 :3).

Hal demikian diatur dalam Pasal 50 ayat (2) UU Merek 2001, yang berbunyi:

Selain penegasan mengenai penggunaan Merek Kolektif sebagaimana dimaksud pada ayat (1) Permohonan tersebut wajib disertai salinan ketentuan penggunaan Merek tersebut sebagai Merek Kolektif, yang 
ditandatangani oleh semua pemilik Merek yang bersangkutan". Syarat ini merupakan tambahan pada persyaratan permintaan pendaftaran Merek biasa.

Seperti halnya mengenai persyaratan, tata cara pengajuan permohonan pendaftaran, pemeriksaan kelengkapan dan pemeriksaan substantif serta pendaftaran Merek Kolektif, tuntuk sepenuhnya kepada ketentuan pendaftaran Merek biasa. Apabila Pemeriksa Merek berkesimpulan permohonan pendaftaran sebagai Merek Kolektif dapat disetujui, maka Kantor Merek akan mecatat Merek tersebut dalam Daftar Umum Merek dengan melampirkan salinan peraturan penggunaan Merek Kolektif. Kemudian, pendaftaran Merek Kolektif berikut salinan peraturan penggunaannya akan diumumkan dalam Berita Resmi Merek. Perbedaan pencatatan pendaftaran dalam Daftar Umum Merek maupun pengumuman dalam Berita Resmi Merek antara Merek biasa dengan Merek Kolektif hanya terletak pada "lampiran". Pada Merek Kolektif, pencatatan pendaftaran dan pengumuman harus ikut melampirkan salinan ketentuan peraturan penggunaan Merek Kolektif. Masa perlindungan hukum atau jangka waktu bagi perlindungan hak Merek biasa maupun hak Merek Kolektif adalah sama, yakni selama 10 tahun, dan dapat diperpanjang. Kemudian, dalam sertifikat Merek Kolektif, kode nomor agenda dan nomor sertifikat pada pokoknya sama dengan Merek biasa. Hanya saja, dalam kolom nama pemilik terdaftar dituliskan semua pemilik dari Merek Kolektif yang tercantum dalam permohonan pendaftaran Merek.

Sesuai dengan ketentuan bahwa hak Merek itu diberikan pengakuannya oleh negara, maka pendaftaran atas Mereknya merupakan suatu keharusan apabila ia menghendaki agar menurut hukum dipandang sah sebagai pihak yang berhak atas Merek. Pendaftaran Merek akan memberikan perlindungan yang lebih kuat khususnya jika menghadapi Merek yang identik atau yang mirip. Bagi pihak yang mendaftarkan Mereknya tersebut, terdapat suatu kepastian hukum bahwa dialah yang berhak atas pemilikan dan penggunaan Merek tersebut. Sebaliknya, bagi pihak lain yang mencoba untuk mendaftar Merek yang sama atau mirip dengan Merek terdaftar untuk barang atau jasa yang sejenis, DJHKI akan menolak pendaftaran tersebut. (Drs. Muhammad Djumhana dan R. Djubaedillah, 2003).

\section{b. Strategi Pelaksanaan}

Dasar pertimbangan dari pembuatan UU Merek adalah untuk mewujudkan persaingan usaha yang sehat, serta memberikan layanan yang baik kepada masyarakat terkait dengan perlindungan Merek yakni melalui pendaftaran Hak Merek. Dalam hal ini, dasar pertimbangan tersebut dikaitkan dengan konteks tujuan UU Merek untuk:

1) Membuat pengusaha tidak mau melakukan peniruan atau pemalsuan atas Merek;

2) Membuat pengusaha berkeinginan dan secara sukarela mendaftarkan Mereknya ke Direktorat Jenderal Hak Kekayaan Intelektual (“DJHKI”); dan

3) Membuat pengusaha bekerjasama dalam memajukan usahanya dengan memanfaatkan perlindungan Merek Kolektif.

Perbedaan bidang tersebut sedikit banyak dapat mempengaruhi pemanfaatan Merek dan pentingnya perlindungan hukum Merek bagi usaha karawo mereka. Wawancara awal dengan beberapa responden pengusaha kerajinan Karawo mengindikasikan temuan sebagai berikut: 
1) Bahwa pengrajin karawo yang memiliki workshop tidak terlalu memanfaatkan Merek atau menganggap Mereknya penting, karena mereka biasanya membuat karawo kosongan (tanpa label Merek) berdasarkan pesanan dari pihak lain;

2) Bahwa pengrajin karawo yang sekaligus memiliki showroom memanfaatkan Merek untuk menandai dan membedakan produk mereka dari produk karawo pengusaha lainnya;

3) Bahwa pemilik showroom karawo yang bukan merupakan pengrajin, kurang menganggap Merek karawo penting, karena mereka biasanya menjual berbagai macam karawo dari berbagai pengrajin dengan Merek karawo yang berbeda-beda;

4) Bahwa Merek bukan menjadi faktor yang utama untuk menarik konsumen membeli karawo, melainkan berdasarkan pada kualitas dan motif karawonya;

5) Bahwa sebagian besar dari mereka tidak resah menghadapi persaingan dengan „karawo" impor dikarenakan mereka menganggap produk karawo mereka telah memiliki pasar tersendiri dan konsumen mampu membedakan mana yang merupakan karawo lokal dan mana yang „karawo" impor;

6) Bahwa beberapa alasan yang membuat mereka tidak tertarik untuk mendaftar Merek ke DJHKI adalah prosedurnya yang birokratis, dan Merek bukan menjadi faktor yang utama konsumen membeli produk karawo.

Ada kecenderungan bahwa pemilik rumah produksi tidak memandang penting untuk memiliki Mereknya sendiri, dikarenakan sebagian besar pesanan yang mereka produksi berasal dari pembeli yang sudah memiliki Merek sendiri. Sedangkan, para pemilik toko atau showroom saja (tidak memiliki workshop karawo) cenderung untuk membangun Merek tokonya, sementara Merek produk karawonya (label yang ditempelkan pada produk karawo), tidak terlampau dianggap penting oleh mereka. Meskipun Merek bukan dianggap sebagai faktor yang utama untuk memenangkan persaingan dan menarik konsumen, dapat dikatakan bahwa rata-rata responden memahami bahwa mereka tidak seharusnya meniru Merek orang lain, dan pendaftaran atas Merek dapat lebih memberikan hak perlindungan hukum untuk penggunaan Merek tersebut. Selain daripada itu, rata-rata dari pengusaha juga menganggap bahwa produk karawo mereka memiliki ciri khas yang membedakannya dengan produk karawo lain, namun korelasinya dengan keinginan mereka untuk memanfaatkan dan mendaftarkan Merek masih perlu dikaji lebih lanjut. Temuan juga menunjukkan bahwa sebagian besar dari mereka ingin mendaftarkan hak Merek ke DJHKI meskipun keinginan tersebutterganjal beberapa hal, seperti: tidak mengetahui prosedur pendaftaran Merek, menunggu Mereknya terkenal, dan belum menjadi prioritas untuk mendukung usaha. Rata-rata responden mengetahui, bahwa ketika terdapat pihak lain yang meniru Merek mereka, kepemilikan hak atas Merek (terdaftar) dapat menguatkan posisi mereka untuk menuntut pihak yang meniru tersebut.

\section{Penutup}

Berdasarkan hasil penelitian hingga saat ini, diketahui bahwa pemanfaatan Merek dan pentingnya perlindungan hukum Merek bagi pengusaha karawo bervariasi dan bergantung pula kepada jenis atau bidang usaha mereka, apakah: pemilik workshop atau rumah produksi batik, pemilik toko atau showroom karawo, atau pemilik keduanya. Namun ratarata responden menyatakan bahwa faktor utama untuk menarik konsumen 
adalah kualitas dan motif atau desain karawonya.Rata-rata responden juga tidak mau meniru Merek pengusaha lain, dan memahami bahwa pendaftaran atas hak Merek dapat memperkuat perlindungan atas penggunaan Merek miliknya. Tidak tampak adanya permasalahan dalam kaitannya dengan penggunaan Merek untuk produk batik. Oleh karena hampir tidak adanya kasus sengketa Merek di kalangan pengusaha kerajanian karawo. Lalu, keinginan para pengusaha karawo untuk menggunakan dan mendaftar Merek Kolektif pun beragam, akan tetapi rata-rata responden menganggap bahwa produk karawo yang mereka hasilkan memiliki ciri khas kedaerahan.

Pemerintah khususnya lebih mensosialisasikan tentang pendftaran merek Khusus sulaman karawo ini di daftarkan juga indikasi geografisnya karena sulaman karawo ini sudah menjadi milik masyarakat gorontalo bahkan sudah menjadi salah satu ciri khas daerah gorontalo terhadap usaha besar yang dilakukan agar supaya setiap pengusaha khsusnya pengusaha pengrajin karawo bisa mempertahankan merek pada suatu kerajinan tersebut sehingga peniruan merek bisa di kenakan sanksi.

\section{Daftar Pustaka}

\section{a. Buku}

Arthur R Miller, Michael Davis, Intellectual Property, Patent, Trademarks and Copyright, 1990,UK: West Publishing Co

Drs. Muhammad Djumhana dan R. Djubaedillah,2003, Hak Milik Intelektual: Sejarah, Teori dan Prakteknya di Indonesia,Bandung: Citra Aditya Baktis

Ihsan Budi Maulana,2000, Ridwan Khairandy dan Nurjihad, Kapita Selekta Hak Kekayaan Intelektual I ,Yogyakarta: Pusat Studi Hukum UII

Irawan Indras, 2008. Judul Skripsi :Pelaksanaan Undang-Undang Nomor 15 Tahun 2001 Tentang Merek Pada Produksi Batik Brotoseno Di Sragen

Kartini Mulyadi dan Gunawan Widjaya,2003,Kebendaan Pada Umumnya, Bogor, Persada Media

Moh. Hidayat Koniyo, 2015. Jurnal Perancangan Aplikasi Rekomendasi Motif Karawo Berdasarkan Karakter Pengguna Berbasis Budaya Gorontalo (Website : jurnal.ftumj.ac.id/index.php/semnastek)

Soerjono Soekanto, 1986,Pengantar Penelitian Hukum, Jakarta, UI-Press.

Rahmatiah, 2017. Judul Jurnal Sulam Karawo:Kontruksi Identitas Budaya Gorontalo, ideas Jurnal Pendidikan, sosial dan budaya Volume 03 / Nomor 01, Februari 2017

\section{b. Sumber Rujukan Dari Website}

https:/ / www.bernas.id/49170-belajar-sulam-ala-gorontalo-ini-4-langkahmembuat-sulam-karawo khas-gorontalo.html (Berita Jawa Pos pada tanggal 12 September 2017)

https:/ /gorontaloholiday.wordpress.com/2012/06/17/karawo-sulam-khasdan-langka-dari gorontalo/23 agustus 2018

http://jhp.ui.ac.id/index.php/home/article/viewFile/32/32 (Agus Sardjono, Brian Amy Prastyo, dan Desrezka Gunti Larasati)

"Intellectual Property for Business Series Number 1: Membuat Sebuah Merek",http://www.wipo.int/export/sites/www/sme/en/documents/gu ides/translation/making_a_mark_indo.pdf, 10 sept 2018. 